\title{
PENGARUH PERSEPSI KUALITAS, CITRA MEREK DAN PERSEPSI NILAI TERHADAP KEPUASAN UNTUK MENINGKATKAN LOYALITAS PELANGgAN (Studi Pada Produk Laptop Merek Asus)
}

\author{
Komang Ayu Indah Paramitha ${ }^{1}$ \\ A.A Gede Agung Artha Kusuma ${ }^{2}$ \\ ${ }^{1,2}$ Fakultas Ekonomi dan Bisnis Universitas Udayana (Unud), Bali, Indonesia \\ e-mail : ayuindahparamitha@gmail.com
}

\begin{abstract}
ABSTRAK
Penelitian ini bertujuan untuk menjelaskan pengaruh persepsi kualitas, citra merek dan persepsi nilai terhadap kepuasan untuk meningkatkan loyalitas pelanggan. Penelitian ini dilakukan di Kota Denpasar yang melibatkan 105 responden melalui metode purposive sampling dan pengumpulan data dilakukan dengan menyebarkan kuesioner yang berisi pernyataan berkaitan dengan variabel persepsi kualitas, citra merek, persepsi nilai, kepuasan pelanggan dan loyalitas pelanggan. Teknik analisis data yang digunakan adalah teknik analisis jalur dan uji asumsi klasik. Hasil penelitian ini menemukan bahwa persepsi kualitas, citra merek dan persepsi nilai berpengaruh positif dan signifikan terhadap kepuasan pelanggan. Kepuasan pelanggan juga memiliki pengaruh positif dan signifikan terhadap loyalitas pelanggan. Hal ini menunjukkan bahwa meningkatkan loyalitas pelanggan, perusahaan diharapkan mampu mempertahankan dan fokus mengenai persepsi kualitas, citra merek dan persepsi nilai, maka dapat meningkatkan kepuasan pelanggan sehingga loyalitas pelanggan akan meningkat.
\end{abstract}

Kata kunci: persepsi kualitas, citra merek, persepsi nilai, kepuasan, loyalitas pelanggan

\begin{abstract}
The purpose of this study is to explain the effect of quality perception, brand image and perception of value on satisfaction to improve customer loyalty. This research was conducted in Denpasar City involving 105 respondents through purposive sampling method and data collection was done by distributing questionnaires containing statement related to variable of perception of quality, brand image, perception value, customer satisfaction and customer loyalty. Data analysis technique used is path analysis technique. The results of this study found that the perception of quality, brand image and perception of value have a positive and significant impact on customer satisfaction. Customer satisfaction also has a positive and significant influence on customer loyalty. This shows that improving customer loyalty, the company is expected to maintain and focus on the perception of quality, brand image and value perception, it can increase customer satisfaction so that will increase customer loyalty.
\end{abstract}

Keywords:quality perception, brand image, value perception, customer satisfaction, customer loyalty. 


\section{PENDAHULUAN}

Era globalisasi memberikan dampak cukup besar terhadap industri teknologi informasi yang mengalami perkembangan secara pesat, ditandai dengan masyarakat yang tidak lepas dari teknologi informasi. Teknologi informasi berperan penting dalam menunjang aktivitas masyarakat sehari-harinya, oleh itu diharapkan dapat mengefesienkan waktu dengan baik. Adanya perkembangan teknologi informasi yang sangat pesat, menuntut masyarakat terutama bagi yang bekerja dan pelajar memiliki perangkat teknologi informasi yang sesuai. Beberapa perangkat yang terkait penggunaan teknologi informasi antara lain, smartphone, PC computer, laptop atau notebook dan tablet (APJII, 2016). Dalam kategori produk laptop banyak sekali merek yang beredar di pasar, antara lain Acer, Asus, Apple, Dell, Lenovo, Hp, Samsung, Toshiba, dan lain-lain.

Asus dihasilkan oleh perusahaan Asustek Computer Ink yang berasal dari Taiwan. Perusahaan ini sudah mampu bersaing di pasar global dengan perusahaan-perusahaan lainnya untuk menyaingi produk-produk berteknologi tinggi, seperti memproduksi produk laptop, smartphone, komponen PC, Tablet, Motherboards, Graphicscard, Keyboard, Sound, Wearable, dan networking (Asus.com). Perusahaan Asus sangat memperhatikan segi kualitas produk dalam proses pembuatannya, karena kualitas merupakan hal terpenting bagi Asus untuk selalu memperbaiki proses manajemen kualitas dan memastikan para konsumen dapat menikmati produk berkualitas tinggi dengan harga yang terjangkau. Laptop Asus banyak diminati oleh masyarakat dikarenakan memiliki keunggulan dibandingkan pesaingnya diantaranya, kualitas spesifikasi, desain dan memiliki 
daya tahan (Exotekno.com). Selain itu kisaran harga yang ditawarkan asus menyasar segmen pasar kelas menegah (Kompas.com).

Data yang disajikan oleh IDC (Internasional Data Corporation) di Indonesia, menunjukkan terdapat tiga vendor besar dalam penjualan laptop atau notebook yaitu Asus, Lenovo, dan Acer. Tabel 1.1 menunjukkan data pangsa pasar laptop atau notebook Tahun 2014-2016.

Tabel 1.

Pangsa Pasar Laptop atau Notebook Tahun 2014-2016 di Indonesia

\begin{tabular}{cccccccc}
\hline \multicolumn{2}{c}{ Asus } & \multicolumn{2}{c}{ Acer } & \multicolumn{2}{c}{ Lenovo } & Total \\
Tahun & $\begin{array}{c}\text { Pangsa } \\
\text { Pasar } \\
(\%)\end{array}$ & $\begin{array}{c}\text { Pertumbuhan } \\
(\%)\end{array}$ & $\begin{array}{c}\text { Pangsa } \\
\text { Pasar } \\
(\%)\end{array}$ & $\begin{array}{c}\text { Pertumbuhan } \\
(\%)\end{array}$ & $\begin{array}{c}\text { Pangsa } \\
\text { Pasar } \\
(\%)\end{array}$ & $\begin{array}{c}\text { Pertumbuhan } \\
(\%)\end{array}$ & $\begin{array}{c}\text { Pangsa } \\
\text { Pasar } \\
(\%)\end{array}$ \\
\hline 2014 & 32,06 & & 19,06 & & 15,07 & & 66,19 \\
2015 & 37,18 & 4,4 & 20,00 & 1,6 & 21,00 & 10,45 & 78,18 \\
2016 & 47,07 & 8,5 & 19,40 & 1,02 & 20,64 & 1,02 & 87,11 \\
\hline
\end{tabular}

Sumber: www.idc.com

Dimulai tahun 2014-2016 data menunjukkan pangsa pasar Asus mengalami peningkatan di tahun 2014-2015 sebesar 4,4\% dan meningkat secara derastis sebesar 8,5\% di tahun 2016. Data tersebut menunjukkan laptop Asus telah memiliki pangsa pasar yang lebih kuat dibandingkan pesaingnya yakni Acer tahun 2014-2015 mengalami peningkatan pangsa pasar sebesar 1,6\% namun mengalami penurunan sebesar 1,02\% ditahun 2016. Pangsa pasar Lenovo tahun 2014-2015 juga mengalami peningkatkan sebesar $10,45 \%$ namun mengalami penurunan tahun 2016 sebesar 1,02\%. Hasil IDC menunjukkan bahwa sampai tahun 2016 laptop merek Asus telah mampu menguasai pasar di Indonesia dengan tren yang semangkin meningkat. Hal ini menunjukkan bahwa Asus semakin diminati oleh masyarakat. 
Berdasarkan Tabel 1 menunjukkan Asus sebagai pemimpin pasar terlihat dari pergerakan trennya yang kian meningkat, sangat penting untuk menjaga loyalitas pelanggan. Salah satu faktor kunci yang menjadi perhatian perusahaan adalah memelihara loyalitas pelanggan (Mise et al., 2013). Pelanggan yang loyal dapat dibentuk dari perasaan puas setelah memiliki pengalaman menggunakan produk (Singh, 2006). Menghadirkan produk berkualitas dapat dihasilkan dengan menawarkan harga yang terjangkau serta membangun citra produk yang kuat, sehingga dapat digunakan perusahaan untuk menciptakan loyalitas pelanggan (Chaeriah, 2016).

Kepuasan merupakan kunci dalam menciptakan loyalitas pelanggan (Chang dan Fong, 2010). Kepuasan pelanggan mencerminkan penilaian seseorang tentang hasil kinerja produk yang dikaitkan dengan ekspetasi. Jika kinerja sebuah produk tidak memenuhi ekspetasi, maka pelanggan akan merasakan tidak puas dan kecewa sedangkan produk yang sesuai dengan ekspetasi, pelanggan akan memperlihatkan perasaan senangnya (Kotler \& Keller, 2009:176). Pelanggan yang loyal akan meningkatkan peluang keuntungan dan cakupan pangsa pasar yang luas bagi perusahaan, karena faktor penentu mencapai kesuksesan dalam menciptakan pelanggan yang loyal adalah perusahaan mampu menciptakan kepuasan (Pramudyo, 2012). Meningkatkan kepuasan pelanggan menjadi kewajiban perusahaan Asus agar mampu menjaga loyalitas pelanggan. Hasil penelitian menemukan kepuasan pelanggan memiliki pengaruh secara positif dan signifikan terhadap loyalitas pelanggan (Arokiasamy, 2010). Hasil penelitian sebelumnya menunjukkan bahwa loyalitas pelanggan sangat ditentukan oleh 
kepuasan pelanggan, itu berarti perusahaan yang menginginkan pelanggan tetap loyal, sangat penting untuk menjaga agar pelanggan tetap puas terhadap produknya.

Ada beberapa faktor yang menentukan kepuasan pelanggan, diantaranya persepsi kualitas. Perusahaan Asus dalam menghasilkan suatu produk yang berkualitas, perlu memiliki persepsi kualitas yang tepat agar sesuai dengan fungsi dan kegunaannya. Persepsi kualitas adalah persepsi konsumen terhadap keseluruhan kualitas atau keunggulan suatu produk atau jasa pelayanan berkaitan dengan apa yang diharapkan oleh konsumen (Rivai dan Wahyudi, 2017). Persepsi kualitas yang dirasakan oleh konsumen berpengaruh terhadap kesedian konsumen untuk membeli sebuah produk (Chapman dan Wahlers, 1999). Hasil penelitian menemukan bahwa persepsi kualitas berpengaruh positif dan signifikan terhadap kepuasan pelanggan (Liao, 2008). Menjaga kualitas menjadikan salah satu cara perusahaan dalam meningkatkan kepuasan pelanggan. Oleh itu semakin berkualitas produk yang ditawarkan oleh perusahaan maka kepuasan yang dirasakan oleh pelanggan semakin tinggi (Lasander, 2013). Selain mempengaruhi kepuasan pelanggan, persepsi kualitas memiliki pengaruh positif dan signifikan terhadap loyalitas pelanggan (Simanihuruk, 2015). Perusahaan Asus sangat memperhatikan segi kualitas produknya agar pelanggan merasa puas, sehingga dapat meningkatkan loyalitas pelanggan.

Selain faktor persepsi kualitas, citra merek merupakan faktor dalam menciptakan kepuasan pelanggan (Chen, 2010). Membangun citra merek yang positif dapat mempengaruhi pembelian ulang karena citra merek yang kuat dapat 
menuntun ke arah kepuasan pelanggan (Andreani et al., 2012). Hasil penelitian menemukan citra merek berpengaruh positif dan signifikan terhadap kepuasan pelanggan (Zakaria, 2017). Citra merek yang positif merupakan suatu penghargaan yang diperoleh oleh perusahaan atas keunggulan yang dimiliki dibandingkan pesaing lainnya, maka perusahaan termotivasi dalam mengembangkan produknya dengan menciptakan inovasi baru guna memenuhi kebutuhan konsumen (Burmannn et al., 2008). Selain mempengaruhi kepuasan pelanggan, citra merek memiliki pengaruh positif dan signifikan terhadap loyalitas pelanggan (Fajarianto dkk., 2013). Citra merek yang kuat membuat konsumen merasakan kepercayaan diri dalam menggunakan produk yang sudah dibeli dan memperlihatkan perasaaan senangnya karena puas dengan produk yang dimiliki, sehingga menigkatkan loyalitas pelanggan.

Selain faktor persepsi kualitas dan citra merek, persepsi nilai juga sangat berpengaruh terhadap kepuasan pelanggan. Menurut Kotler dan Keller (2009:136) persepsi nilai adalah perbedaan antara penilaian pelanggan dari semua manfaat yang dirasakan dan semua biaya yang dikeluarkan. Persepsi nilai yang diperoleh pelanggan dapat tercipta dengan baik pada saat sebelum melakukan pembelian atau setelah melakukan pembelian (Patterson dan Spreng, 1997). Keinginan pelanggan untuk melakukan pembelian kembali dipengaruhi oleh nilai yang dirasakan pelanggan (Cronin et al., 2000). Nilai pelanggan juga dapat merefleksikan persepsi pelanggan atas atribut kualitas dan fungsi harga yang diyakini memiliki pengaruh terhadap keputusan transaksi (Risdwiyanto dan saputra, 2016). Konsumen menekankan bahwa keuntungan yang diterima dari 
suatu produk atau jasa merupakan komponen yang penting dalam nilai (Kusdyah, 2012). Hasil penelitian menemukan bahwa persepsi nilai berpengaruh positif dan signifikan terhadap kepuasan pelanggan (Siry, 2015). Selain menimbulkan kepuasan, persepsi nilai akan mempengaruhi loyalitas pelanggan. Semakin terjangkau harga yang ditetapkan, maka akan meningkatkan loyalitas pelanggan (Tomida dan Satrio, 2016).

Penelitian mengenai persepsi kualitas, citra merek dan persepsi nilai terhadap loyalitas pelanggan pernah dilakukan oleh Saputra (2012). Penelitian tersebut menemukan bahwa persepsi kualitas, citra merek dan persepsi nilai memiliki pengaruh positif dan signifikan terhadap loyalitas. Hasil penelitian yang berbeda ditemukan oleh Nugroho dan Pamungkas (2015) menemukan bahwa persepsi kualitas tidak berpengaruh signifikan terhadap loyalitas pelanggan. Penelitian oleh Sinaga dan Novianti (2016) menemukan bahwa citra merek tidak berpengaruh signifikan terhadap loyalitas pelanggan. Hasil penelitian negatif juga ditemukan oleh Sutanto (2008) menemukan bahwa persepsi nilai tidak berpengaruh signifikan terhadap loyalitas pelanggan. Sejumlah penelitian yang disajikan menemukan adanya hasil yang tidak konsisten dalam hubungan antara variabel persepsi kualitas, citra merek, dan persepsi nilai terhadap loyalitas pelanggan. Karena itu penelitian kembali tentang pengaruh persepsi kualitas, citra merek dan persepsi nilai terhadap kepuasan pelanggan dan loyalitas pelanggan akan diaplikasikan pada produk laptop merek Asus.

Adapun tujuan penelitian ini adalah untuk menjelaskan pengaruh persepsi kualitas, citra merek dan persepsi nilai terhadap kepuasan pelanggan produk 
laptop merek Asus, dan untuk menjelaskan penagaruh kepuasan pelanggan terhadap loyalitas pelanggan produk laptop merek Asus.

Penelitian ini memiliki dua kegunaan, yaitu kegunaan teoritis dan kegunaan praktis. Secara kegunaan teoritis penelitian ini diharapkan mampu memperkaya bidang ilmu manajemen pemasaran secara empiris dan diharapkan mahasiswa dapat mengaplikasikan teori yang didapat sehingga memperoleh wawasan baru dari penelitian ini, sedangkan secara kegunaan praktis, penelitian ini diharapkan dapat memberi masukan dan pertimbangan dalam menetapkan strategi yang tepat di bidang pemasaran serta dapat memperluas pengetahuan dan informasi yang berkaitan dengan penelitian ini.

Menurut Suprapti (2010:68), persepsi merupakan sebuah proses yang dilalui seseorang untuk memillih, mengorganisasi, dan mengintrepretasikan stimuli ke dalam sebuah gambaran tentang dunia, yang memiliki arti atau makna dan bersifat koheren. Menurut Durianto dkk. (2004:96), persepsi kualitas merupakan persepsi pelanggan terhadap keseluruhan kualitas atau keunggulan suatu produk atau jasa layanan berkaitan dengan apa yang diharapkan pelanggan. Persepsi kualitas adalah persepsi pelanggan terhadap keseluruhan kualitas atau keunggulan suatu produk atau jasa layanan berkaitan dengan apa yang diharapkan oleh konsumen (Aaker, 2003). Kualitas yang dirasakan yakni penilaian pelanggan atau meninjau konsistensi spesifikasi produk atau keunggulan dari fungsi produk tersebut (Bhuian, 1997). Kualitas yang dirasakan dipengaruhi oleh faktor-faktor seperti kognisi subyektif pelanggan, skenario lingkungan, dan ciri yang diberikan oleh suatu produk (Zeithaml dan Bitner, 2000). Persepsi kualitas merupakan persepsi 
dari pelanggan, maka tidak dapat ditentukan secara obyektif (Rivai dan Wahyudi, 2017). Persepsi kualitas dipengaruhi oleh dua dimensi, yaitu dalam bentuk kualitas produk dan kualitas jasa (Lindawati, 2005).

Kualitas produk adalah keseluruhan fitur dan karakteristik produk atau layanan yang sesuai dengan kemampuan untuk memuaskan konsumen (Kotler dan Keller, 2009:143). Kualitas produk merupakan hal yang pertama yang dinilai oleh konsumen dan menjadikan suatu pengalaman untuk dapat menarik konsumen, sehingga dapat mempengaruhi kepuasan (Prasastono dkk., 2012). Kualitas produk sangat penting dalam membentuk kepuasan pelanggan serta berkaitan erat dengan menciptakan keuntungan bagi perusahaan (Wijaya dkk., 2017).

Citra merek merepresentasikan asosiasi-asosiasi yang diaktifkan dalam memori ketika berfikir mengenai merek tertentu. Asosiasi tersebut secara sederhana dapat muncul dalam bentuk pemikiran atau citra tertentu yang dikaitkan kepada suatu merek (Shimp, 2014:40). Citra merek adalah persepsi tentang merek yang merupakan refleksi memori konsumen akan asosiasinya pada merek tersebut (Fajarianto dkk., 2013). Citra merek dapat juga diartikan sebagai asosiasi merek yang muncul dalam benak konsumen dalam jangka waktu yang lama dan bersifat konsisten (Koubaa, 2008).

Nilai yang dirasakan oleh pelanggan merupakan faktor penting dalam proses keputusan pembelian pelanggan dan pelanggan akan membeli produk dengan nilai yang dirasakan tinggi (Dodds dan Monroe, 1985). Kesadaran nilai adalah pandangan pelanggan dalam membandingkan manfaat yang dirasakan terhadap produk dan pengorbanan yang diperlukan untuk mendapatkannya (Tarn, 2000). 
Menurut Kotler dan Keller (2009:136) persepsi nilai adalah perbedaan antara penilaian pelanggan dari semua manfaat yang dirasakan dan semua biaya yang dikeluarkan. Penilaian pelanggan terbentuk dari emosional yang terasosiasi mengenai apakah harga yang ditawarkan oleh produsen dan harga yang dibandingkan dengan pesaingnya masuk akal, sehingga dapat diterima oleh konsumen (Lee et al., 2011). Persepsi konsumen tentang harga yang sesuai dengan kualitas produk yang dapat berpengaruh terhadap kepuasan konsumen (Iglesias dan Guillen, 2004).

Kepuasan merupakan perasaan senang atau kecewa seseorang yang timbul karena membandingkan kinerja yang dipersepsikan produk atau hasil terhadap ekspetasi merek (Kotler dan Keller, 2009:139). Pelanggan yang merasakan puas, akan dengan jelas memperlihatkan perasaan senangnya dan memiliki rencana untuk melakukan pembelian ulang (Consuegra et al., 2007). Pelanggan yang merasakan tidak puas akan merespon dengan tindakan yang berbeda antara satu dengan yang lain, seperti hanya mendiamkan saja atau melakukan komplain atas keluhan yang dirasakan (Kotler \& Keller, 2009:176).

Loyalitas adalah komitmen yang dipegang secara mendalam untuk membeli kembali produk atau jasa yang disukai dimasa depan meski pengaruh situasi dan usaha pemasaran berpotensi menyebabkan pelanggan beralih (Kotler dan Keller, 2009:138). Loyalitas merupakan sikap menyenangi terhadap suatu produk yang direpresentasikan dalam pembelian yang konsisten terhadap produk dengan merek yang sama sepanjang waktu (Sutisna, 2001:41). Konsumen yang loyal terhadap suatu merek tertentu dapat disebabkan oleh kualitas produk yang memuaskan, dan 
kualitas pelayanan yang diberikan pengelola toko (Sutisna, 2001:43). Konsumen yang puas akan pelayanan maupun kualitas produk yang dikonsumsinya akan cenderung setia untuk waktu yang lebih lama dan membeli lagi ketika perusahaan memproduksi produk baru ataupun memperbaharui produk lama (Kotler dan Keller, 2009:140). Konsumen yang loyal akan merekomendasikan produk yang penuh dikonsumsinya kepada orang lain (Yu dan Dean, 2000).

Hasil penelitian yang dilakukan oleh Sari dkk. (2012), Salim (2014), Sholihah (2016) Risdwiyanto dan Saputra (2016), serta Chang et al. (2016) menemukan bahwa persepsi kualitas berpengaruh positif dan signifikan terhadap kepuasan pelanggan. Berdasarkan hasil penelitian tersebut, maka dapat diajukan hipotesis sebagai berikut:

$\mathrm{H}_{1}$ : Persepsi kualitas memiliki pengaruh positif dan signifikan terhadap kepuasan pelanggan.

Hasil penelitian yang dilakukan oleh Khan (2012), Kurniawati dkk. (2014), Tjahjaningsih (2013), Suwandi dkk. (2015), Stephen (2007), Tu et al. (2012), Neupane (2015), Pusparani dan Rastini (2014), Susanti dan Wardana (2015), dan Sutopo (2017) menemukan bahwa citra merek memiliki pengaruh positif dan signifikan terhadap kepuasan pelanggan. Berdasarkan hasil penelitian tersebut, maka dapat diajukan hipotesis sebagai berikut:

$\mathrm{H}_{2}$ :Citra merek memiliki pengaruh positif dan signifikan terhadap kepuasan pelanggan.

Hasil penelitian oleh Wibowo dkk. (2014), Yamin (2013), Subagio dkk. (2012), Candra dkk. (2016), dan Siry (2015) menemukan bahwa persepsi nilai memiliki pengaruh positif dan signifikan terhadap kepuasan pelanggan. 
Berdasarkan hasil penelitian tersebut, maka dapat diajukan hipotesis sebagai berikut:

$\mathrm{H}_{3}$ : Persepsi nilai memiliki pengaruh positif dan signifikan terhadap kepuasan pelanggan.

Hasil penelitian yang dilakukan oleh Prabowo (2008), Lubis (2017), Utami dan Khasanah (2016), Normasari dkk. (2013), dan Dharmawansyah (2013) menemukan bahwa kepuasan pelanggan memiliki pengaruh positif dan signifikan terhadap loyalitas pelanggan. Berdasarkan hasil penelitian tersebut, maka dapat diajukan hipotesis sebagai berikut:

$\mathrm{H}_{4}$ : Kepuasan pelanggan memiliki pengaruh positif dan signifikan terhadap loyalitas pelanggan.

Berdasarkan kajian pustaka dan hasil studi empiris sebelumnya, maka kerangka konseptual disusun sebagai berikut,

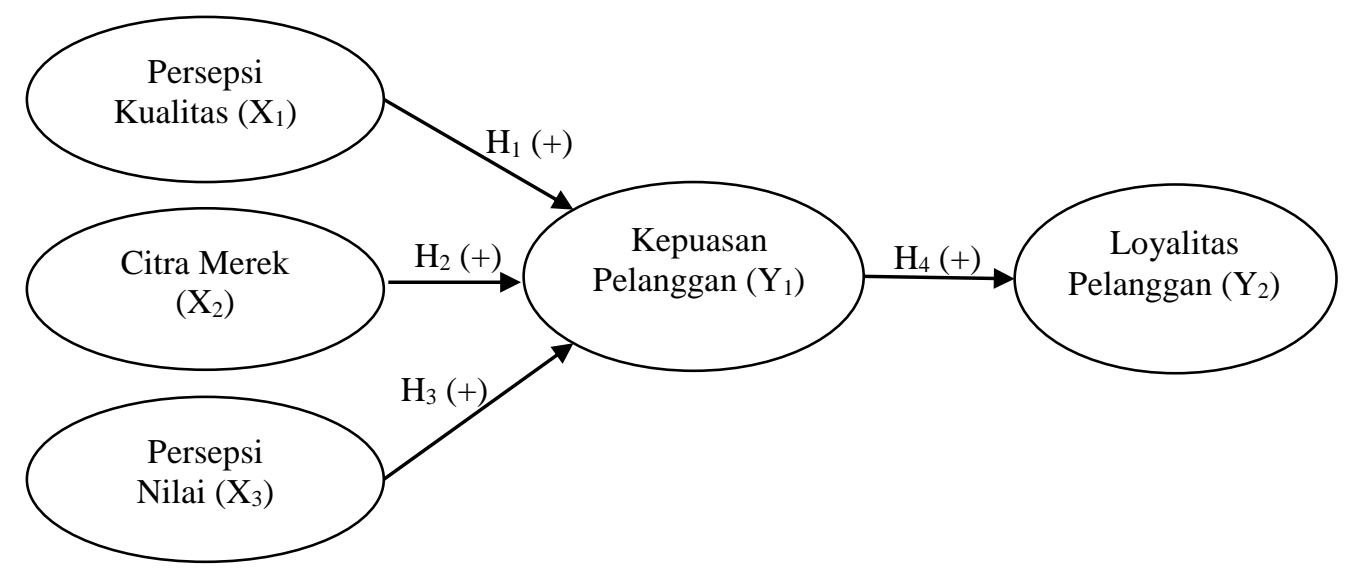

\section{Gambar 1. Kerangka Konseptual}

METODE PENELITIAN

Penelitian ini melakukan pendekatan kuantitatif yang bersifat asosiatif. Penelitian ini dilakukan di Kota Denpasar. Kota ini dipilih karena Kota Denpasar adalah ibukota Provinsi Bali. Kota Denpasar sebagai pusat pendidikan, kesehatan, 
perdagangan dan urbanisasi. Mobilitas yang tinggi di Kota Denpasar mengakibatkan kebutuhan laptop sebagai alat penunjang aktivitas.

Subjek penelitian ini adalah konsumen yang telah mengetahui tentang produk laptop merek Asus dan perilaku konsumen produk laptop merek Asus. Sedangkan objek dari penelitian adalah kepuasan dan loyalitas pelanggan dalam menggunakan produk laptop merek Asus. Penelitian ini menggunakan 3 jenis variabel, yaitu variabel bebas berupa persepsi kualitas $\left(\mathrm{X}_{1}\right)$, citra merek $\left(\mathrm{X}_{2}\right)$ dan persepsi nilai $\left(\mathrm{X}_{3}\right)$. Variabel terikat berupa loyalitas pelanggan $\left(\mathrm{Y}_{2}\right)$. Variabel Intervening berupa kepuasan pelanggan $\left(\mathrm{Y}_{1}\right)$. Dalam mengukut kelima variabel tersebut, digunakan 15 indikator yang disajikan dalam Tabel 2. sebagai berikut,

Tabel 2.

Indikator-indikator Variabel

\begin{tabular}{ccclc}
\hline No. & Variabel & & \multicolumn{1}{c}{ Indikator } & Sumber \\
\hline 1. & Persepsi & $\mathrm{X}_{1.1}$ & Kesesuaian & Kotler dan Keller \\
& Kualitas & $\mathrm{X}_{1.2}$ & Daya tahan & $(2009: 149)$ \\
& & $\mathrm{X}_{1.3}$ & Estetika & Schiffman dan Kanuk \\
2. & Citra Merek & $\mathrm{X}_{2.1}$ & Favorable & $(2016: 135)$ \\
& & $\mathrm{X}_{2.2}$ & Kepercayaan & Shimp (2014:40) \\
& & $\mathrm{X}_{2.3}$ & Manfaat & Nugraheni dan \\
3. & Persepsi & $\mathrm{X}_{3.1}$ & Keterjangkauan harga & Ferdinan (2013) \\
& Nilai & $\mathrm{X}_{3.2}$ & Daya saing harga & \\
& & $\mathrm{X}_{3.3}$ & Kesesuaian harga dengan manfaat & Nurlinda (2013) \\
4. & Kepuasan & $\mathrm{Y}_{1.1}$ & Kepuasan secara keseluruhan & Prastiwi (2012) \\
& Pelanggan & $\mathrm{Y}_{1.2}$ & Konfirmasi harapan & \\
& & $\mathrm{Y}_{1.3}$ & Senang menggunakan produk & Karita. dkk (2015) \\
5. & Loyalitas & $\mathrm{Y}_{2.1}$ & Komitmen & \\
& Pelanggan & $\mathrm{Y}_{2.2}$ & Pembelian ulang & \\
\hline
\end{tabular}

Populasi dari penelitian ini adalah pengguna laptop merek Asus di Kota Denpasar yang tidak diketahui jumlahnya. Penelitian ini dianalisis dengan multivariate, maka jumlah anggota sampel minimal 5 sampai 10 kali dari jumlah indikator yang diteliti (Malhotra, 2004:291). Indikator yang digunakan dalam 
penelitian ini berjumlah 15 buah maka ukuran sampel berada pada rentang 75150. Berdasarkan pertimbangan maka ukuran sampel 7 kali dari jumlah indikator, sehingga ukuran sampel ditetapkan sebanyak 105 responden

Mengingat ukuran populasi tidak dapat diketahui dengan pasti, maka sampel ditentukan menggunakan metode nonprobality sampling. Salah satu metode yang termasuk dalam nonprobality sampling adalah purposive sampling. Pertimbangan kriteria sampel yang digunakan adalah responden berdomisili di Kota Denpasar, Jenjang pendidikan minimal SMA/sederajat dan kisaran umur 18-50 tahun, karena dengan jenjang pendidikan terakhir SMA tersebut responden sudah dapat memahami pernyataan dalam kuesioner dengan baik dan benar, dan responden pengguna produk laptop merek Asus.

Data yang digunakan yakni data kualitatif dan kuantitatif. Data kualitatif berupa penilaian atau jawaban responden terhadap sejumlah pernyataan yang ada dalam kuesioner sedangkan data kuantitatif berupa usia dari responden yang mengisi kuesioner. Sebagian besar data bersumber dari sumber primer yaitu responden yang menjadi anggota sampel. Data yang dikumpulkan dari sumber primer adalah jawaban responden dari kuesioner. Sementara itu, data dari sumber sekunder berupa publikasi pangsa pasar laptop dan smartphone di global oleh Internasional Data Corporation (IDC), publikasi demografi pengunaan internet, perangkat, dan aplikasi di Indonesia oleh Asosiasi Penyelenggara Jasa Internet (APJII), publikasi keseluruhan tentang Asus oleh situs Asus, dan artikel dari situs berita online. 
Data dikumpulkan menggunakan instrumen penelitian berupa kuesioner. Kuesioner terdiri dari pernyataan terbuka dan pernyataan tertutup. Pernyataan tertutup mengenai identitas responden seperti nama, usia, jenis kelamin, dan pekerjaan responden. Pernyataan terbuka terdiri mengenai sejumlah pernyataan yang meminta pendapat responden tentang penilaian terhadap sejumlah indikator dari setiap variabel yang berupa indikator variabel persepsi kualitas, citra merek, persepsi nilai, kepuasan pelanggan dan loyalitas pelanggan. Tiap indikator variabel penelitian diberi pilihan jawaban dengan menggunakan skala Likert.

Sebelum digunakan, instrumen penelitian terlebih dahulu diuji untuk mengetahui validitas dan reliabilitasnya. Pernyataan-pernyataan dalam kuesioner dikatakan valid apabila koefisien korelasi $\geq 0,3$ (Sugiyono, 2016:142). Uji validitas instrumen bertujuan untuk memeriksa apakah kuesioner sebagai instrumen penelitian sudah tepat dalam mengukur indikator penelitian. Uji reliabilitas dilakukan untuk mengetahui konsistensi alat ukur yang digunakan, sehingga bila alat ukur tersebut digunakan kembali maka akan memperoleh hasil yang sama. Uji reliabilitas data dengan menggunakan formula Alpha Cronbach $\geq$ 0,6 (Sugiyono, 2016:147).

Jumlah sampel sebanyak 105 responden, dengan instrumen penelitian berupa kuesioner. Data dikumpulkan dengan metode survei, yaitu menyebarkan kuesioner kepada responden secara langsung di lapangan dan peneliti dibantu oleh teman. Kuesioner diberikan secara umum dengan bertatap muka langsung dengan responden. 
Data yang diperoleh akan dianalisis menggunakan statistik deskriptif dan statistik inferensial. Statistik deskriptif berupa rata-rata usia responden dan ratarata skor jawaban dari kuesioner. Rata-rata skor jawaban responden terhadap indikator-indikator variabel dikelompokkan ke dalam 5 kelas interval dengan rentang penilaian seperti pada Tabel 3 sebagai berikut.

Tabel 3.

Rentang Penelitian Jawaban Responden

\begin{tabular}{ccc}
\hline No & Rentang & Kriteria \\
\hline 1 & $1,00-1,79$ & Sangat Tidak Baik \\
2 & $1,80-2,59$ & Tidak Baik \\
3 & $2,60-3,39$ & Cukup Baik \\
4 & $3,40-4,19$ & Baik \\
5 & $4,20-5,00$ & Sangat Baik \\
\hline \multicolumn{2}{l}{ Sumber: Wirawan,2002 }
\end{tabular}

Statistik inferensial digunakan untuk menjawab hipotesis. Dalam penelitian ini, statistik inferensial digunakan adalah analisis jalur (path analysis) dan uji asumsi klasik.

\section{HASIL DAN PEMBAHASAN}

Jumlah responden yang menjadi anggota sampel sebanyak 105 responden. Profil responden yang diklasifikasikan berdasarkan demografi berupa umur, jenis kelamin, pekerjaan dan telah memenuhi kriteria yang ditetapkan dalam kriteria responden penelitian diantaranya berpendidikan minimal SMA/SMK, berdomisili di Kota Denpasar. Karakteristik responden dalam penelitian ini disajikan pada Tabel 4 sebagai berikut. 
Tabel 4.

Profil Responden

\begin{tabular}{|c|c|c|c|c|}
\hline No. & Variabel & Klasifikasi & $\begin{array}{l}\text { Jumlah } \\
\text { (Orang) }\end{array}$ & $\begin{array}{c}\text { Persentase } \\
(\%)\end{array}$ \\
\hline \multirow[t]{6}{*}{1.} & Usia & $18-22$ tahun & 60 & 57,1 \\
\hline & & 23 - 27 tahun & 35 & 33,3 \\
\hline & & 28 - 32 tahun & 5 & 4,8 \\
\hline & & 33 - 37 tahun & 3 & 2,9 \\
\hline & & $>37$ tahun & 2 & 1,9 \\
\hline & & Jumlah & 105 & 100,0 \\
\hline \multirow[t]{3}{*}{2.} & Jenis Kelamin & Perempuan & 69 & 65,7 \\
\hline & & Laki-laki & 36 & 34,3 \\
\hline & & Jumlah & 105 & 100,0 \\
\hline \multirow[t]{5}{*}{3.} & Pekerjaan & Mahasiswa & 77 & 73,3 \\
\hline & & Karyawan Swasta & 13 & 12,4 \\
\hline & & PNS & 10 & 9,5 \\
\hline & & Wiraswasta & 5 & 4,8 \\
\hline & & Jumlah & 105 & 100,0 \\
\hline
\end{tabular}

Sumber : data diolah, 2018

Tabel 4 menunjukkan sebagian besar responden didominasi oleh responden yang berusia pada rentang 18-22 tahun sebesar 57,1\%. Pada jenis kelamin, respoden didominsasi oleh perempuan sebesar $65,7 \%$. Sebesar $62,9 \%$ responden berpendidikan minimal SMA/sederajat dan pekerjaan responden didominasi oleh mahasiswa sebesar $73,3 \%$.

Tabel 5.

Hasil Uji Validitas dan Reliabilitas

\begin{tabular}{|c|c|c|c|c|}
\hline No. & Variabel & Indikator & $\begin{array}{c}\text { Koefisien } \\
\text { Korelasi }\end{array}$ & $\begin{array}{c}\text { Koefisien } \\
\text { Reliabilitas }\end{array}$ \\
\hline \multirow[t]{3}{*}{1.} & Perepsi Kualitas & Kesesuaian & 0,769 & 0,727 \\
\hline & & Daya tahan & 0,858 & \\
\hline & & Estetika & 0,795 & \\
\hline \multirow[t]{3}{*}{2.} & Citra Merek & Favorable & 0,765 & 0,765 \\
\hline & & Kepercayaan & 0,868 & \\
\hline & & Manfaat & 0,830 & \\
\hline \multirow[t]{3}{*}{3.} & Persepsi Nilai & Daya saing harga & 0,833 & 0,797 \\
\hline & & Keterjangkauan harga & 0,870 & \\
\hline & & Kesesuaian manfaat & 0,841 & \\
\hline \multirow[t]{3}{*}{4.} & Kepuasan & Kepuasan secara keseluruhan & 0,895 & 0,870 \\
\hline & Pelanggan & Konfirmasi harapan & 0,879 & \\
\hline & & Senang menggunakan produk & 0,901 & \\
\hline \multirow[t]{3}{*}{5.} & Loyalitas & Komitmen & 0,923 & 0,886 \\
\hline & Pelanggan & Pembelian ulang & 0,901 & \\
\hline & & Rekomendasi & 0,894 & \\
\hline
\end{tabular}

Sumber : data diolah, 2018 
Data pada Tabel 5 menunjukkan hasil dari uji validitas dan reliabilitas instrument penelitian. Koefisien korelasi dari masing - masing indikator lebih besar dari 0,3 sehingga instrumen yang digunakan telah tepat untuk mengukur indikator dalam penelitian. Koefisien reliabilitas (Alpha Cronbach) masing masing variabel lebih besar dari 0,6 sehingga instrument yang digunakan merupakan instrument yang memiliki konsistensi yang baik.

Deskripsi data variabel menggambarkan penilaian dari pernyataan yang terdapat dalam kuesioner penelitian. Rata-rata skor dari jawaban responden akan dinilai berdasarkan kriteria yang telah disajikan pada Tabel 6, sebagai berikut,

Tabel 6.

Penilaian Responden Terhadap Masing - Masing Variabel

\begin{tabular}{|c|c|c|c|c|c|c|c|}
\hline \multirow{2}{*}{ Variabel } & \multirow{2}{*}{ Indikator } & \multicolumn{5}{|c|}{ Distribusi Jawaban (\%) } & \multirow{2}{*}{$\begin{array}{c}\text { Rata - } \\
\text { rata skor }\end{array}$} \\
\hline & & 1 & 2 & 3 & 4 & 5 & \\
\hline \multirow{4}{*}{$\begin{array}{l}\text { Persepsi } \\
\text { Kualitas }\end{array}$} & Kesesuaian & 0 & 0 & 5,7 & 69,5 & 24,8 & 4,19 \\
\hline & Daya Tahan & 0 & 1,9 & 21,0 & 52,4 & 24,8 & 4,00 \\
\hline & Estetika & 0 & 2,9 & 18,1 & 61,9 & 17,1 & 3,93 \\
\hline & & & & & \multicolumn{2}{|c|}{ Total } & 4,04 \\
\hline \multirow[t]{4}{*}{ Citra Merek } & Favorable & 0 & 1,0 & 8,6 & 61,9 & 28,6 & 4,22 \\
\hline & Kepercayaan & 0 & 1,0 & 30,5 & 54,3 & 14,3 & 3,86 \\
\hline & Manfaat & 0 & 1,9 & 10,5 & 68,6 & 19,0 & 4,09 \\
\hline & & & & & \multicolumn{2}{|c|}{ Total } & 4,05 \\
\hline \multirow[t]{4}{*}{ Persepsi Nilai } & Keterjangkauan harga & 1,0 & 2,9 & 16,2 & 55,2 & 24,8 & 4,00 \\
\hline & Daya saing harga & 0 & 1,9 & 14,3 & 66,7 & 17,1 & 3,99 \\
\hline & Kesesuaian manfaat & 1,0 & 1,9 & 13,3 & 63,8 & 20,0 & 4,00 \\
\hline & & & & & \multicolumn{2}{|c|}{ Total } & 4,00 \\
\hline \multirow{4}{*}{$\begin{array}{l}\text { Kepuasan } \\
\text { Pelanggan }\end{array}$} & Kepuasan secara keseluruhan & 0 & 1,0 & 16,2 & 60,0 & 22,9 & 4,04 \\
\hline & Konfirmasi harapan & 0 & 1,0 & 20,0 & 61,9 & 17,1 & 3,94 \\
\hline & Senang menggunakan produk & 1,0 & 1,0 & 20,0 & 58,1 & 20,0 & 3,94 \\
\hline & & & & & \multicolumn{2}{|c|}{ Total } & 3,97 \\
\hline \multirow{4}{*}{$\begin{array}{l}\text { Loyalitas } \\
\text { Pelanggan }\end{array}$} & Komitmen & 1,0 & 5,7 & 31,4 & 43,8 & 18,1 & 3,72 \\
\hline & Pembelian ulang & 1,0 & 7,6 & 41,0 & 32,4 & 18,1 & 3,59 \\
\hline & Rekomendasi & 0 & 1,0 & 26,7 & 51,4 & 21,0 & 3,92 \\
\hline & & & & & \multicolumn{2}{|c|}{ Total } & 3,75 \\
\hline
\end{tabular}

Sumber : data diolah, 2018 
Variabel persepsi kualitas memiliki skor rata-rata sebesar 4,04, hasil ini masuk dalam kategori baik. Secara keseluruhan responden memiliki penilaian yang baik terhadap persepsi kualitas dimiliki laptop merek Asus. Indikator kesesuaian memiliki rata-rata skor tertinggi sebesar 4,19. Indikator tersebut memperlihatkan sebesar $69,5 \%$ responden setuju dan $24,8 \%$ responden sangat setuju bahwa laptop merek Asus memiliki kesesuaian dengan spesifikasi berupa kualitas yang ditawarkan sesuai dengan standar produksi. Indikator estetika memiliki rata-rata skor terendah sebesar 3,93. Indikator tersebut memperlihatkan sebesar $61,9 \%$ responden setuju dan $17,1 \%$ responden sangat setuju bahwa laptop merek Asus memiliki estetika berupa tampilan desain yang menarik.

Variabel citra merek memiliki skor rata-rata sebesar 4,05, hasil ini masuk dalam kategori baik. Secara keseluruhan memiliki penilaian yang baik terhadap citra dimiliki laptop merek Asus. Indikator favorable memiliki rata-rata skor tertinggi sebesar 4,22. Indikator tersebut memperlihatkan sebesar 61,9\% responden setuju dan $28,6 \%$ responden sangat setuju bahwa laptop merek Asus memiliki penilaian merek yang mudah diingat oleh konsumen. Skor rata-rata terendah dimiliki oleh indikator kepercayaan sebesar 3,86. Indikator tersebut memperlihatkan sebesar $54,3 \%$ responden setuju dan $14,3 \%$ responden sangat setuju bahwa laptop merek Asus memiliki kepercayaan berupa meningkatkan rasa percaya diri penggunanya.

Variabel persepsi nilai memiliki skor rata-rata sebesar 4,00, hasil ini masuk dalam kategori baik. Secara keseluruhan responden memiliki tingkat kepuasan yang baik terhadap produk laptop merek Asus. Rata-rata skor tertinggi dimiliki 
oleh indikator keterjangkauan harga dan kesesuaian manfaat sebesar 4,00. Indikator tersebut memperlihatkan sebesar $55,2 \%$ responden setuju dan $24,8 \%$ responden sangat setuju bahwa laptop merek Asus memiliki keterjangkauan harga berupa harga yang ditawarkan merupakan harga yang sesuai dengan daya beli konsumen. Sebesar $63,8 \%$ responden setuju dan $20,0 \%$ responden sangat setuju bahwa laptop merek Asus memiliki kesesuaian manfaat berupa harga yang ditawarkan sebanding dengan manfaat yang dirasakan oleh konsumen. Indikator daya saing harga memiliki skor terendah sebesar 3,99. Indikator tersebut memperlihatkan sebesar $66,7 \%$ responden setuju dan $17,1 \%$ responden sangat setuju bahwa laptop merek Asus memiliki daya saing harga berupa harga yang ditawarkan merupakan harga yang bersaing dengan produk laptop merek lainnya.

Variabel kepuasan pelanggan memiliki rata-rata sebesar 3,97, hasil ini masuk dalam kategori baik. Secara keseluruhan responden memiliki tingkat kepuasan yang baik terhadap produk laptop merek Asus. Rata-rata skor tertinggi dimiliki oleh indikator kepuasan secara keseluruhan sebesar 4,04. Indikator tersebut memperlihatkan sebesar $60,0 \%$ responden setuju dan $22,9 \%$ responden sangat setuju bahwa kepuasan muncul saat pelanggan menggunakan produk laptop merek Asus. Indikator konfirmasi harapan dan senang menggunakan produk memiliki skor rata-rata terendah sebesar 3,94. Indikator tersebut memperlihatkan sebesar $61,9 \%$ responden setuju dan $17,1 \%$ responden sangat setuju bahwa konfirmasi harapan muncul saat kualitas dari laptop merek Asus mampu memenuhi apa yang diharapkan oleh pelanggan. Sebesar 58,1\% 
responden setuju dan 20,0\% responden sangat setuju bahwa senang menggunakan produk laptop merek Asus.

Variabel loyalitas pelanggan memiliki rata-rata skor sebesar 3,75, hasil ini masuk kedalam kategori baik. Secara keseluruhan responden memiliki tingkat loyalitas yang baik terhadap produk laptop merek Asus. Rata-rata skor tertinggi dimiliki oleh indikator rekomendasi sebesar 3,92. Indikator tersebut memperihatkan sebesar 51,4\% responden setuju dan 21,0 responden sangat setuju bahwa pelanggan loyal terhadap produk laptop merek Asus akan merekomendasikan produk yang sudah digunakannya kepada orang lain. Rata-rata skor terendah dimiliki oleh indikator pembelian ulang sebesar 3,59. Indikator tersebut memperlihatkan sebesar $32,4 \%$ responden setuju dan $18,1 \%$ responden sangat setuju bahwa pelanggan yang loyal akan melakukan pembelian ulang produk laptop merek Asus jika mengeluarkan laptop varian baru.

Tabel 7.

Hasil Uji Normalitas Persamaan Regresi 1

\begin{tabular}{ll}
\hline & Unstandardized Residual \\
\hline $\mathrm{N}$ & 105 \\
Kolmogorov Smirnov & 1,202 \\
Asymp. Sig. (2-tailed) & 0,111 \\
\hline Sumber: Data diolah, 2018 &
\end{tabular}

Tabel 7 menunjukkan bahwa nilai Kolmogorov Smirnov $(K-S)$ sebesar 1,202 sedangkan nilai Asymp. Sig. (2-tailed) sebesar 0,111. Hasil tersebut mengindikasikan bahwa model persamaaan regresi tersebut berdistribusi normal karena nilai Asymp. Sig. (2-tailed) sebesar 0,111 lebih besar dari nilai alpha yaitu 0,05 . 
Tabel 8.

Hasil Uji Normalitas Persamaan Regresi 2

\begin{tabular}{ll}
\hline & Unstandardized Residual \\
\hline $\mathrm{N}$ & 105 \\
Kolmogorov Smirnov & 1,220 \\
Asymp. Sig. (2-tailed) & 0,102 \\
\hline Sumber: Data diolah, 2018 &
\end{tabular}

Tabel 8 menunjukkan bahwa nilai Kolmogorov Smirnov $(K-S)$ sebesar 1,220 sedangkan nilai Asymp. Sig. (2-tailed) sebesar 0,102. Hasil tersebut mengindikasikan bahwa model persamaaan regresi tersebut berdistribusi normal karena nilai Asymp. Sig. (2-tailed) sebesar 0,102 lebih besar dari nilai alpha yaitu 0,05 .

Tabel 9.

Hasil Uji Multikolinieritas Persamaan Regresi 1

\begin{tabular}{lcc}
\hline Variabel & Tolerance & VIF \\
\hline Persepsi Kualitas & 0,619 & 1,616 \\
Citra Merek & 0,415 & 2,410 \\
Persepsi Nilai & 0,533 & 1,875 \\
\hline \multicolumn{2}{l}{ Sumber: Data diolah, 2018}
\end{tabular}

Tabel 9 menunjukkan bahwa nilai tolerance dan VIF dari varibel persepsi kualitas, citra merek dan persepsi nilai. Hasil itu mengindikasikan bahwa nilai tolerance untuk setiap variabel lebih besar dari $10 \%$ dan nilai VIF lebih kecil dari 10 yang berarti model persamaan regresi 1 bebas dari multikolinieritas.

Tabel 10.

Hasil Uji Multikolinieritas Persamaan Regresi 2

\begin{tabular}{lll}
\hline Variabel & Tolerance & VIF \\
\hline Kepuasan Pelanggan & 1,000 & 1,000 \\
\hline Sumber: Data diolah, 2018 &
\end{tabular}

Tabel 10 menunjukkan nilai tolerance untuk setiap variabel lebih besar dari $10 \%$ dan nilai VIF lebih kecil dari 10 yang berarti model persamaan regresi 2 bebas dari multikolinieritas. 
Tabel 11.

Hasil Uji Heteroskedastisitas Persamaan Regresi 1

\begin{tabular}{|c|c|c|c|c|c|c|}
\hline \multirow[t]{2}{*}{ Model } & & \multicolumn{2}{|c|}{$\begin{array}{l}\text { Unstandardized } \\
\text { Coefficients }\end{array}$} & \multirow{2}{*}{$\begin{array}{l}\text { Standardized } \\
\text { Coefficients } \\
\text { Beta } \\
\end{array}$} & \multirow[t]{2}{*}{$\mathbf{T}$} & \multirow[t]{2}{*}{ Sig. } \\
\hline & & B & Std. Error & & & \\
\hline \multirow[t]{4}{*}{1} & (Constant) & 1,624 & 0,632 & & 2,570 & 0,012 \\
\hline & Persepsi Kualitas & 0,027 & 0,058 & 0,057 & 0,459 & 0,647 \\
\hline & Citra Merek & $-0,059$ & 0,071 & $-0,126$ & $-0,830$ & 0,901 \\
\hline & Persepsi Nilai & $-0,038$ & 0,055 & $-0,094$ & $-0,701$ & 0,485 \\
\hline
\end{tabular}

Sumber: Data diolah, 2018

Tabel 11 menunjukkan bahwa nilai signifikansi dari variabel persepsi kualitas sebesar 0,647 , citra merek sebesar 0,901 dan persepsi nilai sebesar 0,485 lebih besar dari 0,05 itu berarti tidak terdapat pengaruh antara variabel bebas terhadap absolut residual. Dengan demikian, model yang dibuat tidak mengandung gejala heteroskedastisitas.

Tabel 12.

Hasil Uji Heteroskedastisitas Persamaan Regresi 2

\begin{tabular}{|c|c|c|c|c|c|c|}
\hline \multirow[t]{2}{*}{ Model } & & \multicolumn{2}{|c|}{$\begin{array}{l}\text { Unstandardized } \\
\text { Coefficients }\end{array}$} & \multirow{2}{*}{$\begin{array}{l}\text { Standardized } \\
\text { Coefficients } \\
\text { Beta } \\
\end{array}$} & \multirow[t]{2}{*}{$\mathbf{t}$} & \multirow[t]{2}{*}{ Sig. } \\
\hline & & B & Std. Error & & & \\
\hline \multirow[t]{2}{*}{1} & (Constant) & 0,374 & 0,640 & & 0,585 & 0,560 \\
\hline & Kepuasan pelanggan & 0,071 & 0,053 & 0,132 & 1,347 & 0,181 \\
\hline
\end{tabular}

Sumber: Data diolah, 2018

Tabel 12 menunjukkan bahwa nilai signifikansi dari variabel kepuasan pelanggan sebesar 0,181 . Nilai tersebut lebih besar dari 0,05 yang berarti tidak terdapat pengaruh antara variabel bebas terhadap absolut residual.

Tabel 13.

Hasil Analisis Jalur Persamaan Regresi 1

\begin{tabular}{|c|c|c|c|c|c|}
\hline \multirow[t]{2}{*}{ Model } & \multicolumn{2}{|c|}{$\begin{array}{c}\text { Unstandardized } \\
\text { Coefficients }\end{array}$} & \multirow{2}{*}{$\begin{array}{c}\begin{array}{c}\text { Standardized } \\
\text { Coefficients }\end{array} \\
\text { Beta }\end{array}$} & \multirow[t]{2}{*}{$\mathbf{t}$} & \multirow[t]{2}{*}{ Sig. } \\
\hline & B & Std. Error & & & \\
\hline (Constant) & $-0,042$ & 0,937 & & $-0,045$ & 0,964 \\
\hline Persepsi Kualitas & 0,180 & 0,086 & 0,157 & 2,088 & 0,039 \\
\hline Citra Merek & 0,359 & 0,105 & 0,312 & 3,411 & 0,001 \\
\hline Persepsi Nilai & 0,458 & 0,081 & 0,455 & 5,635 & 0,000 \\
\hline $\mathrm{R}_{1}{ }^{2} \quad: 0,648$ & & & & & \\
\hline F Statistik : 62,037 & & & & & \\
\hline Sig. $\quad: 0,000$ & & & & & \\
\hline
\end{tabular}


Data yang disajikan pada Tabel 13 maka persamaan struktural untuk hipotesis 1, 2, dan 3 dapat disusun sebagai berikut:

$$
\begin{array}{ll}
\mathrm{Y}_{1} & =\beta_{1} \mathrm{X}_{1}+\beta_{2} \mathrm{X}_{2}+\beta_{3} \mathrm{X}_{3}+\mathrm{e}_{1} \ldots \ldots \ldots \ldots \ldots \ldots \ldots \ldots \\
\mathrm{Y}_{1} & =0,157 \mathrm{X}_{1}+0,312 \mathrm{X}_{2}+0,455 \mathrm{X}_{3}+\mathrm{e}_{1}
\end{array}
$$

Keterangan:

$\mathrm{Y}_{1} \quad=$ Kepuasan pelanggan

$\mathrm{X}_{1} \quad=$ Persepsi kualitas

$\mathrm{X}_{2} \quad=$ Citra merek

$\mathrm{X}_{3} \quad=$ Persepsi nilai

$\beta=$ Koefisien garis regresi

$\mathrm{e}_{1} \quad=$ eror 1

Hasil pada Tabel 13 diketahui pengaruh persepsi kualitas terhadap kepuasan pelanggan memiliki koefisien $\beta_{1}$ sebesar 0,157 dan $\rho$ value sebesar 0,039 . Nilai koefisien $\beta_{1}>0$ dan $\rho$ value $\leq 0,05$ mengindikasikan $\mathbf{H}_{1}$ diterima dan $\mathrm{H}_{0}$ ditolak. Hasil ini berarti persepsi kualitas berpengaruh positif dan signifikan terhadap kepuasan pelanggan. Pengaruh citra merek terhadap kepuasan pelanggan memiliki koefisien $\beta_{2}$ sebesar 0,312 dan $\rho$ value sebesar 0,001 . Nilai koefisien $\beta_{2}>0$ dan $\rho$ value $\leq$ 0,05 mengindikasikan $\mathbf{H}_{2}$ diterima dan $\mathrm{H}_{0}$ ditolak. Hasil ini berarti citra merek berpengaruh positif dan signifikan terhadap kepuasan pelanggan. Pengaruh persepsi nilai terhadap kepuasan pelanggan memiliki koefisien $\beta_{3}$ sebesar 0,455 dan $\rho$ value sebesar 0,000 . Nilai koefisien $\beta_{3}>0$ dan $\rho$ value $\leq 0,05$ mengindikasikan $\mathbf{H}_{3}$ diterima dan $\mathrm{H}_{0}$ ditolak. Hasil ini berarti persepsi nilai berpengaruh positif dan signifikan terhadap kepuasan pelanggan.

Hasil pengolahan data untuk persamaan regresi 2 disajikan pada Tabel 14. sebagai berikut. 
Tabel 14.

Hasil Analisis Jalur Persamaan Regresi 2

\begin{tabular}{|c|c|c|c|c|c|}
\hline \multirow{2}{*}{ Model } & \multicolumn{2}{|c|}{$\begin{array}{c}\text { Unstandardized } \\
\text { Coefficients }\end{array}$} & \multirow{2}{*}{$\begin{array}{c}\begin{array}{c}\text { Standardized } \\
\text { Coefficients }\end{array} \\
\text { Beta }\end{array}$} & \multirow{2}{*}{$\mathbf{t}$} & \multirow{2}{*}{ Sig. } \\
\hline & B & $\begin{array}{c}\text { Std. } \\
\text { Error }\end{array}$ & & & \\
\hline (Constant) & 0,576 & 1,038 & & 0,555 & 0,580 \\
\hline Kepusan Pelanggan & 0,892 & 0,086 & 0,715 & 10,384 & 0,000 \\
\hline
\end{tabular}

F Statistik : 1

Sig. F $: 0,000$

Sumber : data diolah, 2018

Data yang disajikan pada Tabel 14, maka persamaan struktural untuk hipotesis 4 dapat disusun sebagai berikut:

$$
\begin{array}{ll}
\mathrm{Y}_{2} & =\beta_{4} \mathrm{Y}_{1}+\mathrm{e}_{1} \ldots \ldots \\
\mathrm{Y}_{2} & =0,715 \mathrm{Y}_{1}+\mathrm{e}_{2}
\end{array}
$$

Keterangan:

$\mathrm{Y}_{2} \quad=$ Loyalitas pelanggan

$\mathrm{Y}_{1} \quad=$ Kepuasan pelanggan

$\beta \quad=$ Koefisien garis regresi

$\mathrm{e}_{2} \quad=$ eror 2

Hasil pada Tabel 14 diketahui pengaruh kepuasan pelanggan terhadap loyalitas pelanggan memiliki koefisien $\beta_{4}$ sebesar 0,715 dan $\rho$ value sebesar 0,000. Nilai koefisien $\beta_{4}>0$ dan $\rho$ value $\leq 0,05$ mengindikasikan $\mathrm{H}_{4}$ diterima dan $\mathrm{H}_{0}$ ditolak. Hasil ini berarti persepsi nilai berpengaruh positif dan signifikan terhadap kepuasan pelanggan.

Berdasarkan persamaan regresi 1 dan persamaan regresi 2, diketahui nilai $\mathrm{R}_{1}^{2}=0,648$ dan $\mathrm{R}_{2}^{2}=0,511$, maka nilai $\mathrm{e}_{1}$ sebesar 0,761 dan $\mathrm{e}_{2}$ sebesar 0,857. Nilai $\mathrm{e}_{1}$ dan $\mathrm{e}_{2}$ yang telah diketahui maka hasil koefisien determinasi total adalah 0,575 memiliki arti bahwa sebesar 57,5\% variasi loyalitas pelanggan dipengaruhi oleh variasi persepsi kualitas, citra merek, persepsi nilai, dan kepuasan pelanggan, 
sedangkan sisanya sebesar $42,5 \%$ dijelaskan oleh faktor lain yang tidak dimasukkan ke dalam model.

Hasil pengujian hipotesis 1 berupa pengaruh persepsi kualitas terhadap kepuasan pelanggan menunjukkan hasil yang diterima. Hal ini mengindikasikan bahwa persepsi kualitas berpengaruh positif dan signifikan terhadap kepuasan pelanggan. Itu berarti, semakin baik persepsi kualitas laptop merek Asus, maka akan semakin tinggi kepuasan pelanggan terhadap produk laptop merek Asus. Hasil rangkuman penilaian responden yang disajikan dalam deskripsi variabel penelitian menunjukkan bahwa penilaian responden terhadap persepsi kualitas berada dalam kategori baik sehingga menghasilkan tingkat kepuasan berada dalam kategori baik. Responden merasa puas dengan kesesuaian dimiliki produk laptop merek Asus berupa spesifikasi yang ditawarkan berkualitas tinggi. Strategi Asus dalam menjadikan kualitas spesifikasi sebagai keunggulan kompetitifnya akan berhasil meningkatkan kepuasan pelanggan. Hasil penelitian ini didukung dengan penelitian sebelumnya yang dilakukan oleh Sholilah (2016), Risdwiyanto dan Saputra (2016), Salim (2014), Sari dkk. (2012), dan Chang et al. (2016) yang menunjukkan bahwa persepsi kualitas berpengaruh positif dan signifikan terhadap kepuasan pelanggan

Hasil pengujian hipotesis 2 berupa pengaruh citra merek terhadap kepuasan pelanggan menunjukkan hasil yang diterima. Hal ini mengindikasikan bahwa citra merek berpengaruh positif dan signifikan terhadap kepuasan pelanggan. Itu berarti, semakin baik citra merek yang dimiliki produk laptop merek Asus, maka akan semakin tinggi kepuasan pelanggan. Hasil rangkuman penilaian responden 
yang disajikan dalam deskripsi variabel penelitian menunjukkan bahwa penilaian responden terhadap citra merek berada dalam kategori baik sehingga menghasilkan tingkat kepuasan berada dalam kategori baik. Responden merasa puas dengan merek yang dimiliki produk laptop merek Asus. Strategi Asus dalam membangun citra merek yang kuat agar mudah dingat konsumen meskipun banyak merek yang beredar dipasar membuat konsumen puas dengan produk laptop merek Asus sehingga mampu meningkatkan kepuasan pelanggan.Hasil penelitian ini didukung dengan penelitian sebelumnya yang dilakukan oleh Khan (2012), Kurniawati dkk. (2014), Tjahjaningsih (2013), Suwandi dkk. (2015), Tu et al. (2012), Neupane (2015), Pusparani dan Rastini (2014), Susanti dan Wardana (2015), dan Sutopo (2017) yang menunjukkan bahwa citra merek berpengaruh positif dan signifikan terhadap kepuasan pelanggan.

Hasil pengujian hipotesis 3 berupa pengaruh persepsi nilai terhadap kepuasan pelanggan menunjukkan hasil yang diterima. Hal ini mengindikasikan bahwa persepsi nilai berpengaruh positif dan signifikan terhadap kepuasan pelanggan. Itu berarti, semakin baik persepsi nilai konsumen terhadap produk laptop merek Asus, maka akan semakin tinggi kepuasan pelanggan. Hasil rangkuman penilaian responden yang disajikan dalam deskripsi variabel penelitian menunjukkan bahwa penilaian responden terhadap persepsi nilai berada dalam kategori baik sehingga menghasilkan tingkat kepuasan berada dalam kategori baik. Responden merasa puas dengan keterjangkauan harga dan kesesuian manfaat yang diberikan produk laptop merek Asus. Strategi Asus dengan fokus menyasar konsumen segmen menengah menjadikan Asus menawarkan harga yang 
lebih terjangkau dengan tetap menjaga kualitas mampu meningkatkan kepuasan pelanggan. Konsumen merasa puas terhadap kesesuian manfaat yang dirasakan dengan harga yang dibayarkan saat menggunakan laptop merek Asus. Hasil penelitian ini didukung dengan penelitian sebelumnya yang dilakukan oleh Wibowo dkk. (2014), Yamin (2013), Subagio dkk. (2012), Candra dkk. (2016), dan Siry (2015) yang menunjukkan bahwa persepsi nilai berpengaruh positif dan signifikan terhadap kepuasan pelanggan.

Hasil pengujian hipotesis 4 berupa pengaruh kepuasn pelanggan terhadap loyalitas pelanggan menunjukkan hasil yang diterima. Hal ini mengindikasikan bahwa kepuasan pelanggan berpengaruh positif dan signifikan terhadap loyalitas pelanggan. Itu berarti, semakin baik kepuasan yang dirasakan pelanggan produk laptop merek Asus, maka akan semakin tinggi pula loyalitas pelanggan terhadap produk laptop merek Asus. Hasil rangkuman penilaian responden yang disajikan dalam deskripsi variabel penelitian menunjukkan bahwa kepuasan pelanggan berada dalam kategori baik sehingga menghasilkan tingkat loyalitas pelanggan berada dalam kategori baik. Responden menjadi pelanggan yang loyal karena merasa puas dengan produk laptop merek Asus dan akan merekomendasikan kepada orang lain. Persepsi kualitas, citra merek dan persepsi nilai laptop merek Asus mampu meningkatkan kepuasan pelanggan. Strategi Asus dalam meningkatkan kepuasan pelanggan dengan menghadirkan persepsi kualitas yang baik, citra merek yang kuat dan persepsi nilai yang sesuai daya beli akan mampu meningkatkan loyalitas pelanggan. Pelanggan yang loyal ini akan merekomendasikan produk laptop merek Asus ke orang lain, sehingga akan 
membantu perusahaan dalam mendatangkan konsumen baru. Hasil penelitian ini didukung dengan penelitian sebelumnya yang dilakukan oleh Prabowo (2008), Lubis (2017), Utami dan Khasanah (2016), Normasari dkk. (2013), dan Dharmawansyah (2013) menunjukkan bahwa kepuasan pelanggan berpengaruh positif dan signifikan terhadap loyalitas pelanggan.

Hasil penelitian ini memiliki implikasi teoritis dan praktis. Secara teoritis penelitian ini menunjukkan pengaruh positif dan signifikan dari persepsi kualitas, citra merek dan persepsi nilai terhadap kepuasan pelanggan serta kepuasan pelanggan berpengaruh positif dan signifikan terhadap loyalitas pelanggan. Oleh karena itu, penelitian ini dapat menambah kajian empiris dan memperkuat penelitian sebelumnya bahwa saat perusahaan ingin meningkatkan loyalitas pelanggan.

Implikasi praktis dari penelitian ini adalah para perusahaan Asus harus lebih memperhatikan kepuasan pelanggan yang ditentukan oleh persepsi kualitas, citra merek dan persepsi nilai. Persepsi nilai memiliki nilai yang tertinggi berdasarkan penelitian namun terdapat beberapa hal yang perlu diperhatikan khususnya pada keterjangkauan harga sehingga mampu meningkatkan kepuasan pelanggan. Diposisi kedua, citra merek memiliki nilai yang tertinggi namun terdapat beberapa hal yang perlu diperhatikan khususnya pada membangun citra merek yang kuat sehingga mampu meningkatkan kepuasan pelanggan. Diposisi ketiga, persepsi kualitas memiliki nilai yang tertinggi namun terdapat beberapa hal yang perlu diperhatikan khususnya pada kesesuaian berupa spesifikasi sehingga mampu meningkatkan kepuasan pelanggan. Jika perusahaan ingin mempertahankan, maka 
hal paling utama memperhatikan kembali variabel persepsi nilai, citra merek dan persepsi kualitas agar lebih baik.

\section{SIMPULAN DAN SARAN}

Simpulan yang dapat diberikan berdasarkan pembahasan hasil penelitian yang telah dilakukan, sebagai berikut: Persepsi kualitas, citra merek dan persepsi nilai berpengaruh positif dan signifikan terhadap kepuasan pelanggan. Hasil penelitian menunjukkan bahwa semakin baik persepsi kualitas, citra merek dan persepsi nilai yang dimiliki produk laptop merek Asus, maka akan semakin tinggi pula kepuasan pelanggan. Kepuasan pelanggan berpengaruh positif dan signifikan terhadap loyalitas pelanggan. Hasil penelitian menunjukkan bahwa semakin tinggi kepuasan terhadap produk laptop merek Asus, maka akan semakin tinggi pula loyalitas pelanggan. Persepsi nilai yang dimiliki produk laptop merek Asus merupakan variabel yang paling mempengaruhi tingkat kepuasan pelanggan. Persepsi nilai produk laptop merek Asus berupa keterjangkauan harga dan kesesuaian manfaat.

Bagi perusahaan, agar menjaga dan mempertahankan estetika produk, meningkatkan kepercayaan konsumen melalui produk yang ditawarkan, memperhatikan daya saing harga melalui harga yang ditawarkan, memperhatikan konfirmasi harapan dari konsumen untuk mengetahui keluhan dan saran dari konsumen yang menggunakan laptop merek Asus dan merancang strategi baru melalui inovasi terhadap produknya guna dapat menarik konsumen agar ingin melakukan pembelian kembali laptop merek Asus. 


\section{REFERENSI}

Aaker, David A. 2003. The Power of Branded Diferentator. Sloan Management Review, 45(1), pp. 85-86.

Adreani, Fransisca., Taniaji, Tan Lucy dan Puspitasari, Ruth Natalia Made. 2012. The Impact of Brand Image Towards Loyalty With Satisfaction as a Mediator in Mcdonald's. Jurnal Manajemen dan Kewirausahaan, 14(1), hal.64-71.

Alma, Buchari. 2005. Manajemen Pemasaran dan Pemasaran Jasa. Bandung: Alfabeta.

Anonymous. 2017. Filosofi Perusahaan Asus. http://www.asus.com/id/About ASUS/Formula kemenangan/. Diakses 7 Juli 2016.

Anonymous. 2017. 10 Laptop Asus Paling Laris Beserta Harga dan Spesifikasi. http://exotekno.com/laptop-asus-paling-laris/. Diakses pada 11 September 2017.

Arokiasamy, Anantha Raj. A. 2010. The Impact of Customer Satisfaction on Customer Loyalty and Intentions to Switch In The Banking Sector In Malaysia. The Journal of Commerce, 5(1), pp.14-21.

Asosiasi penyelenggara Jasa Internet Indonesia dan Mastel. 2016. Konklusi Survey Ekosistem DNA (Device, Network, \& Apps). http://apjii.or.id. Diakses pada 8 juli 2017.

Bhuian,S.N. 1997. Marketing Cues and Perceived Quality: Percepyions of Saudi Consumers Toward Products Of The U.S, Japan, Germany, Italy, U.K. and France. Journal of Quality Management, 2(2), pp.217-235.

Bilson, Simamore. 2002. Panduan Riset Perilaku Konsumen. PT Gramedia Pustaka Utama, Jakarta.

Burman, C., K, Schaefer and P. Maloney. 2008. Industry Image: It's Impact on The Brand Image of Potential Employess. Journal of Brand Management, 16(3), pp.159-176.

Candra, Afrimon., Kamener, Dahliana dan Irda. 2016. Pengaruh Kualitas Pelayanan dan Persepsi Nilai Terhadap Kepuasan Konsumen Menggunakan BPJS Kesehatan Di Kota Padang. E-Jurnal Universitas Bung Hatta, 9(2), hal. 1-12.

Chaeriah, Ella Siti. 2016. Pengaruh Harga, Citra Merek, Dan Kualitas Produk Terhadap Loyalitas Pengguna Smartphone Samsung (Studi PADA Mahasiswa Magister Manajemen UNKRIS). Jurnal Manajemen Bisnis Krisnadwipayana, 4(3), hal. 1-9. 
Chapman, Joe dan Russ Wahlers. 1999. A Revision and Empirical Test Of The Extended Price Perceived Quality Model. Journal of Marketing, 7(3), pp.5364.

Chang, Nai Jen and Cher, Min Fong. 2010. Green Product Quality, Green Corporate Image, Green Customer Satisfaction and Green Customer Loyalty. African Journal of Business Management, 4(13), pp.2836-2844.

Chang, Ching Chung., Wu, Hsueh Ying., Lin, Hsing Hui., dan Chang, Hsiung Yun. 2016. A Study of Customers Perceived Quality, Perceived Value, Expectation and Satisfaction To It's Brand Loyalty: The Case Of Global Trotter Sportswear In Taiwan. Journal American Society of Business and Behavioral Sciences, 23(1), pp: 112-119.

Chen, Y S. 2010. The Driver of Green Brand Equity; Green Brand Image, Green Satisfaction and Green Trust. Journal of Business Ethics, 9(3), pp.307-319.

Consuegra, David Martin, Arturo Molina, dan Agueda Esteban. 2007. An Integrated Model of Price, Satisfaction and Loyalty: An Empirical Analysis In The Service Sector. Journal of Product and Brand Management, 16(7), pp.459-468.

Cronin, Joseph. J., Brady, Michael K, dan Hult, G. Tomas M. 2000. Assessing The Effects of Quality, Value, and Satisfaction on Consumer Behavioral Intentions In Service Enviroments. Journal of Retailing, 76(2), pp.193-218.

Dharmawansyah, Inggil. 2013. Pengaruh Experiential Marketing dan Kepuasan Pelanggan Terhadap Loyalitas Pelanggan (Studi Kasus Pada Rumah Makan Pring Asri Bumi Ayu), Management Analysis Journal. 2(2), hal.1-10.

Dodds, William. B., Monroe, Kent B., dan Grewal, Dhruv. 1991. Effect of Price, brand and Store Information on Buyers Product Evaluations. Journal of Marketing Research, 28(3), pp. 307-319.

Durianto, Darmadi., Sugiarto dan Sitinjak, Tony. 2004. Strategi Menaklukkan Pasar Melalui Riset Ekuitas dan Perilaku Merek. Jakarta: PT. Gramedia Pustaka Utama.

Fajarianto, Bayu., Lubis, Nawa Zirul dan Suryadi. 2013. Pengaruh Kualitas Pelayanan dan Brand Image Terhadap Loyalitas Pelanggan Melalui Kepuasan Pelanggan CV. AHASS Sahabat Sejati Motor Tembalang Semarang. Diponogoro Journal of Sosial and Politic, 1(2), hal: 75-100.

Fauzi. 2016. Tak Lagi Nomor Satu, Acer Tetap Sabet Top Brand Awards 2016. http://sellseluller.id/news/2016/02/tak-lagi-nomer-satu-acer-tetap-sabettop-brand-awards-2016/amp/. Diakses 6 Februari 2016.

Ghanimata, Fifyanita, dan Mustafa Kamal. 2012. Analisis Pengaruh Harga, Kualitas Produk, dan Lokasi Terhadap Keputusan Pembelian (Studi Pada Pembelian Produk Bandeng Juwana Erlina Semarang). Diponegoro Journal of Management, 1(2), hal. 1-10. 
Ghozali, Imam, 2009. Aplikasi Analisis Multivariate Dengan Program SPSS, Edisi Keempat. Penerbit Universitas Diponegoro.

Gunawan, Yurianto. 2017. Laptop Asus Paling Larisn di Indonesia Sepanjang Tahun 2016. http://www.jagatreview.com/2017/03/laptop-asus-paling-larisdiindonesia-Sepanjang-Tahun-2016/. Diakses 4 Maret 2017.

Hsiung, Lin Chien. 2011. A Study on The Relationships Between The Brand Image and Customer Satisfaction in Catering Business. African Journal of Business Management, 5(18), pp.7732-7739.

Iglesias, Marta Pedraja dan M. Jesus Yagile Guillen. 2004. Perceived Quality and Price: Their Impact On The Satisfaction Of Restaurant Customers. Internasional Journal of Contemporary Hospital Management, 16(6), hal. 373-379.

Karita, Nyoman Shanti Pranithi., Wardana, I Made., Suasana, I Gusti Agung Ketut Gede. 2015. Peran Kepuasan Pelanggan Dalam Memediasi Pengaruh Kualitas Produk Terhadap Loyalitas Pelanggan Pada Produk Pewangi Pakaian Molto Di Kota Denpasar. E-Jurnal Manajemen Universitas Udayana, 4 (3), hal.715-730.

Khan, Shazad., Husain, Syed Majid., Yaqoob, Fahad. 2012. Determinants of Customer Satisfaction In Fast Food Industry. International Journal of Management and Strategy, 3(4), pp.1-16.

Kotler, Philip dan Gary Armstrong.. 2010. Prinsip-prinsip Pemasaran. Jakarta: Erlangga.

Kotler, Philip and Kevin Lane Keller. 2009. Manajemen Pemasaran Edisi ketiga Belas Jilid 1. Jakarta: Erlangga.

Koubaa, Yamen. 2008. Country of Origin, Brand Image Perpection, and Brand Image Structure. Asia Pacific Journal of Marketing and Logistics, 20(2), pp.139-155.

Kurniawati, Dewi., Suharyono dan Kusumawati, Andriani. 2014. Pengaruh Citra Merek dan Kualitas Produk Terhadap Kepuasan dan Loyalitas Pelanggan (Studi Pada Pelanggan KFC Cabang Kawi Malang). Jurnal Administrasi Bisnis, 14(2), hal.1-9.

Kusdyah, Ike. 2012. Persepsi Harga, Persepsi Merek, Persepsi Nilai, dan Keinginan Pembelian Ulang Jasa Clinic Kesehatan (Studi Kasus Erha Clinic Surabaya). Jurnal Manajemen Pemasaran. 7(1), hal.25-32.

Laksana, Fajar. 2008. Manajemen Pemasaran Edisi 1. Yogjakarta: Graha Ilmu.

Lasander, Chistian. 2013. Citra Merek, Kualitas Produk dan Promosi Pengaruhnya Terhadap Kepuasan Komsumen Pada Makanan Tradisional. Jurnal EMBA, 1(3), hal. 284-293. 
Lee, Simon., Illia, Abdou., dan Body, Assion Lawson. 2011. Perceived Price Fairness Of Dynamic Pricing. Journal Industrial Management and Data System. 111(4), pp.531-550.

Lindawati. 2005. Analisis Kesadaran Merek, Persepsi Kualitas dan Asosiasi Merek dalam Ekstensi Merek Pada Produk Merek Lifebouy di Surabaya. Jurnal Sains Pemasaran Indonesia, 4(1), hal.47-70.

Lubis, Ivan Octora. 2017. Pengaruh Citra Merek, Kualitas Pelayanan, dan Kepuasan Pelanggan Terhadap Loyalitas Pelanggan. Jurnal Ilmu dan Riset Manajemen, 6(5), hal.1-17.

Malhotra, Nareshk. 2006. Riset Pemasaran: Pendekatan Terapan Jilid 1. Jakarta: Indeks.

Mise, J. K., N. Chandrasekeran, O. Odhiambo dan O. Martin. 2013. Exploring The Determinants of Brand Loyalty in Global FMCG Markets of Soft Drink Consumers in Kenya and India. International Journal of Research in Management, 2(3), pp. 1-15.

Moraga, Eduardo, Arturo Z. Vasques Parraga dan Jorge Zamora Gonzales. 2008. Customer Satisfaction and Loyalty: Start With The Product, Culmite With The Brand. Journal of Consumer Marketing, 25(5), pp. 302-313.

Neupane, Remesh. 2015. The Effect of Brand Image on Customer Satisfaction and Loyalty Intention In Retail Supermarket Chain UK. International Journal of Social Sciences Management, 2(1), pp.83-107.

Normasari, Selvy., Sumadji, Srikandi., Kusumawati, Andriani. 2013. Pengaruh Kualitas Pelayanan Terhadap Kepuasan Pelanggan, Citra Perusahaan dan Loyalitas Pelanggan (Survei Pada Tamu Pelanggan yang Menginap di Hotel Pelangi Malang). Jurnal Administrasi Bisnis, 6(2), hal.1-9.

Nugraheni, Rini dan Comaeni Enril Ferdinan. 2013. Analisis Pengaruh Persepsi Harga, Persepsi Kualitas Produk dan Promosi Terhadap Keputusan Pembellian Sepeda Motor Suzuki (Studi Pada Pembeli - Penguna Sepeda Motor Suzuki di Kota Solo). Diponegoro Journal of Management, 2(2), hal. $1-8$.

Nugroho, Anggoro Panji dan Pamungkas, Anton Respati. 2015. Pengaruh Persepsi Kualitas Pelayanan, Persepsi Kualitas Produk dan Trust Terhadap Kepuasan dan Loyalitas Mahasiswa (Studi Pada Stit Adi Unggul Bhirawa Surakarta). Jurnal Bianglala Informatika, 3(2), hal.56-65.

Nurlinda, R.A. 2013. Pengaruh Customer Satisfaction Strategy Terhadap Peningkatan Kepuasan Konsumen. 2013. Forum Ilmiah, 10(2), hal. 172 181.

Patterson, Paul G. dan Spreng, Richard A. 1997. Modelling The Relationship Between Perceived Value, Satisfaction and Repurchase Intention in 
Business to Business, Services Context: an Empirical Examination. International Journal of Services Industry Management, 8(5), pp. 414-434.

Prabowo, Budi. 2008. Pengaruh Relationship Marketing Terhadap Loyalitas Pelanggan Melalui Kepuasan Pelanggan Pada PT Astra Surabaya. Jurnal Ilmu Sosial, 8(2), hal.92-97.

Pramudyo, Anung. 2013. Pengaruh Citra Merek Terhadap Loyalitas Melalui Kepuasan Sebagai Intervening (Studi Pada Mahasiswa Perguruan Tinggi Swasta di Yogjakarta). Jurnal Bisnis Manajemen dan Akuntansi, 1(1), hal.116.

Prasastono, Ndaru dan Pradapa, Sri Yilianto Fajar. 2012. Kualitas Produk dan Kualitas Pelayanan Terhadap Kepuasan Konsumen Kentucky Fried Chicken Semarang Candi. Dinamika Kepariwisataan, 6(2), hal. 15-23.

Priyanto, Dwi. 2008. Mandiri Belajar SPSS. Yogyakarta: Meiako. Hal:39.

Pusparani, Putu Ayu Yulia dan Made Rastini. 2014. Pengaruh Kualitas Produk dan Brand Image Terhadap Kepuasan Konsumen dan Loyalitas Pelanggan Kamera Canon Digital Single Lens Reflex (DSLR) Di Kota Denpasar. EJurnal Manajemen Universitas Udayana, 3(5), hal.1311-1319.

Rajendran, Ragu Prasadh dan Suresh, Jayshree. 2017. Customer Satisfaction Index as A Performance Evaluation Metric: A Study on Indian E-Banking Industry. International Journal of Business, 22(3), pp. 251-274.

Riduwan dan Kuncoro, Engkos Achmad. 2008. Cara Menggunakan dan Memakai Analisis Jalur (Path Analysis). Bandung: Alfabeta.

Risdwiyanto, Andriya dan Saputra, Saktya Ganes. 2016. Peran Citra Merek, Nilai Pelanggan dan Kualitas Persepsian Terhadap Kepuasan Pelanggan (Studi Kasus Modem Smartfren Di Wilayah Kabupaten Sleman Yogjakarta). Jurnal Maksipreneur, 5(2), hal.1-14.

Rivai, Ade Risman dan Wahyudi, Triyono Arief. 2017. Pengaruh Persepsi Kualitas, Citra Merek, Persepsi Harga Terhadap Loyalitas Pelanggan dengan Kepercayaan dan Kepuasan Pelanggan Sebagai Variabel Mediasi. Jurnal Bisnis dan Komunikasi, 4(1), hal. 29-37.

Salim, Fanny Fibriyanti dan Dharmayanti, Diah. 2014. Pengaruh Brand Image dan Perceived Quality Terhadap Kepuasan dan Loyalitas Pelanggan Mobil Toyota di Surabaya. Jurnal Manajemen Pemasaran Petra, 2(1), hal. 1-8.

Subagio, Hartono dan Saputa, Robin. 2012. Pengaruh Perceived Service Quality, Perceived Value, Satisfaction dan Image Terhadap Customer Loyalty (Study Kasus Garuda Indonesia). Jurnal Manajemen Pemasaran, 7(1), hal. 42-51.

Sari, Farah Mutia dan B. Kustijana, Dwi Hastjarja. 2012. Pengaruh Persepsi Kualitas Produk, Persepsi Kualitas Pelayanan dan Trust Pada Kepuasan 
Konsumen di Perusahaan Taksi PT Kosti Solo. Jurnal Fokus Manajerial, 11(2), hal. 183-194.

Singh, H. 2006. The Inportance of Customer Satisfaction in Relation to Customer Loyalty and Retention. Asia Pacific University College of Technology and Innovation WP-06-06, May 2006, Kuala Lumpur,Malaysia.

Schiffman,.L.G and Kanuk, L. L. 2006. Perilaku Konsumen. Jakarta : Indeks.

Shimp, Terence A. 2014. Komunikasi Pemasaran Terpadu dalam Periklanan dan Promosi Edisi 8. Jakarta: Selemba Empat.

Sholiha, Dwi Deniaty. 2016. Pengaruh Persepsi Kualitas Siaran dan Format Siaran Serta Kualitas Penyiar Terhadap Kepuasan dan Loyalitas Pendengar Pada Radio Kiss FM Jember. Jurnal Bisnis dan Manajemen, 10(3), hal. 252264.

Simanihuruk, Peran. 2015. Pengaruh Persepsi Kualitas dan Kepuasan Terhadap Loyalitas Pelanggan Pada Koperasi Kredit (Credit Union) Mandiri Cabang Medan. Jurnal Riset Akuntansi dan Keuangan, 1(1), hal.73-97.

Sinaga, Krisman dan Rini Novianti. 2016. Analisis Pengaruh Citra Merek, Kualitas Produk dan Persepsi Harga Terhadap Loyalitas Konsumen Produk Pasta Gigi Pepsodent. Global, 1(10), hal.1-11.

Siry, Maharany Jana. 2015. Pengaruh Perceived Value Terhadap Kepuasan Pelanggan Pada Jasa Tata Rias Pengantin Tunjung Seto Dengan Kualitas Pelayanan Sebagai Variabel Mediasi. Jurnal Ekonomi dan Kewirausahaan, 15(1), hal. 64-72.

Sri Suprapti, Ni Wayan. 2010. Perilaku Konsumen (Pemahaman Dasar dan Aplikasinya dalam Strategi Pemasaran. Denpasar: Udayana. University Press.

Subagio, Hartono dan Saputra, Robin. 2012. Pengaruh Perceived Service Quality, Perceived Value, Satisfaction dan Image Terhadap Customer Loyalty (Studi Kasus Garuda Indonesia), Jurnal Manajemen Pemasaran, 7(1), hal.42-51.

Sugiyono. 2016. Metode Penelitian Administratif Dilengkapi Dengan Metode $R \&$ $D$. Bandung: Alfabeta.

Susanti, Ni Putu Hani dan I Made Wardana. 2015. Pengaruh Kualitas Produk dan Citra Merek Terhadap Kepuasan dan Loyalitas Pelanggan Pada Produk Kosmetik Hijau Merek The Body Shop. E-Jurnal Manajemen Universitas Udayana, 4(5), hal.622-636.

Sutanto, Jeanne Ananti. 2008. Pengaruh service Quality dan Perceived Value Terhadap Kepuasan dan Loyaltas Konsumen Apartemen Di Kota Surabaya. Jurnal Majalah Ekonomi dan Bisnis Universitas Airlangga, 18(3), hal. 286301. 
Sutisna. 2001. Perilaku Konsumen dan Komunikasi Pemasaran. Bandung: Remaja Rosdakarya.

Sutopo, Oceani. 2017. Analisis Pengaruh Citra Merek, Nilai Pelanggan, dan Kepuasan Pelanggan Tupperware di Magelang. Diponegoro Journal of Management, 6(1), hal: 1-13.

Suwandi., Sularsa., Suroso, Iman. 2015. Pengaruh Kualitas Pelayanan, Harga dan Citra Merek Terhadap Kepuasan dan Loyalitas Pelanggan Pos Ekspres di Kantor Pos Bondowoso dan Sitobondo. Jurnal JEAM, 16 (2), hal: 68-88.

Stephen L. Sondoh Jr., Maznah Wan Omar, Nabsiah Abdul Wahid, Ishak Ismail and Amran Harun. 2007. The Effect of Brand Image on Overall Satisfaction and Loyalty Intention In The Context Of Color Cosmetic. Asian Academy Of Management Journal, 12(1), pp.83-107.

Tarn, Jackie.L.M. 2000. The Effects of Service Quality, Perceived Value and Customer Satisfaction On Behavioral Intentions. Journal of Hospitality and Leisure Maketing, 6(4), pp.31-43.

Tjahjaningsih Endang. 2013. Pengaruh Citra Merek Dan Promosi Terhadap Kepuasan Pelanggan Serta Dampak Terhadap Loyalitas Pelanggan Supermaket Carrefour di Semarang. Media Ekonomi dan Manajemen, 28(2), hal.0854-1442.

Tomida, Merinda., Satrio Budhi. 2016. Pengaruh harga dan citra merek terhadap Loyalitas Pelanggan Produk Footwear Yongki Komaladi. Jurnal Ilmu dan Riset Manajemen, 5(7), hal.1-15.

Tu, Yu Te., Wang, Chin Mei., and Chang, Hsiao Chien. 2012. Corporate Brand Image and Customer Perceived Value and Satisfaction On Loyalty: An Empiricial Study Of Starbucks Coffee In Taiwan. Journal of Sosial and Development Sciences, 3(1), pp.24-32.

Utami, Ayu Arunika, dan Khasanah. 2016. Pengaruh Kualitas Produk, Kualitas Pelayanan dan Citra Merek Terhadap Loyalitas Pelanggan Melalui Kepuasan Pelanggan (Pengguna Apple Iphone di Jurusan Manajemen Universitas Diponoogoro, Semarang. Diponogoro Journal of Management, 5(3), hal.1-9.

Yamin, Regina. 2013. Persepsi Nilai, Persepsi Kualitas, dan Citra Terhadap Kepuasan Konsumen Pada PT ASTRA Internasional Daihatsu di Manado. Jurnal EMBA, 1(3), hal.1231-1240.

Yuliastina, Ni Kadek dan Jatra, Made. 2014. Pengaruh Kualitas Pelayanan Terhadap Kepuasan Konsumen Pada L'Amore Café Di Denpasar. E-jurnal Manajemen Universitas Udayana, 3(2), hal.428-439.

Yu, Yi Ting dan Alison Dean. 2000. The Contribution of Emotional Satisfaction To Consumer Loyalty. International Journal of Service Industry Management, 12(3), hal.234-250. 
Walley, Keith., Paul Custonce and Sam Taylor. 2007. The Importance of Brand In The Industrial Purchase Decision: A Case Study Of The UK Tractor Market. Journal of Business \& Industrial Marketing, 22(6), pp: 383-393.

Wibowo, Setyo Ferry., Sarih, Iin Pusfita dan Murti, Agung Kresna. 2014. Persepsi Kualitas Pelayanan dan Persepsi Nilai Terhadap Kepuasan Pelanggan (Studi Pada Indomaret Palmerah). Jurnal Riset Manajemen Sains Indonesia, 5(2), hal. 304-324.

Widiartanto, Yoga. 2017. Asus Klaim Kuasai Pasar Laptop Indonesia. https://amp.kompas.com./tekno/read/2017/03/15/16483787/asus.klaim.kuas ai.pasar.laptop.Indonesia. Diakses pada 15 Maret 2017.

Wijaya, I Putu Surya Ananta., Nurcaya, I Nyoman. 2017. Kepuasan Pelanggan Memediasi Kualitas Produk dan Kewajaran Harga Terhadap Loyalitas Merek Mcdonald's Di Kota Denpasar. E-Jurnal Manajemen Universitas Udayana, 6(3), hal: 1534-1563.

Wirawan, Nata. 2002. Cara Mudah Memahami Statistik 1 (Statistik Deskriptif). Edisi 1. Denpasar: Keramat Emas.

Zakaria, Diapinasa Gema. 2017. Pengaruh Kualitas Pelayanan, Kualitas Produk, dan Harga Terhadap Kepuasan Pelanggan. Jurnal Ilmu Riset Manajemen, 6(4), hal.1-18.

Zeithaml, Valarie A. 1988. Customer Perceptions of Price, Quality and Value: A Means End Model and Synthesis Of Evidence. Journal of Marketing, 52 (3), pp. 2-22

Zeithaml, Valarie A., and Bitner, M. J. (2000). Service Marketing: Customer Focus Across the Firm. New York: McGraw-Hill. 